\title{
Determinants of Role Structure in Family Financial Management
}

\author{
DENNIS L. ROSEN \\ DONALD H. GRANBOIS*
}

\begin{abstract}
Variables determining the role of husband and wife in family financial management are explored based on in-home, personal interviews. Financial tasks reflecting implementation activities and two groupings of decision activities were related to component-score variables through discriminant function analysis. Sex-role attitude and educational level were most important in determining the role structure of implementation tasks. Locus of control, wife's working status and reasons for work, and a measure of family life cycle were each significant in determining role structure for a grouping of decision tasks.
\end{abstract}

$\mathrm{H}$ igh interest rates, inflationary pressures, and the gradual deregulation of financial institutions have created an environment in which family financial management has assumed great significance. Families' modifications of financial behaviors and adoptions of new practices are evident in the acceptance of new financial services and changes in the mix of savings and investment options favored by consumers. Yet little is known about the family processes underlying these changes.

The roles of husbands and wives in savings and money management are the focus of the study reported here. Research is justified not only because the behavior itself is changing rapidly, but because there is reason to believe that earlier conceptualizations of role structures for all types of family decisions may no longer be valid. Later marriage, decreasing family size, changes in wives' employment status and reasons for employment, and changing attitudes of both men and women toward proper roles for husbands and wives all challenge predictions based upon earlier research (Roberts 1981).

\section{EARLIER RESEARCH}

Previously published studies have had several deficiencies: respondents often have been drawn from narrow and specialized populations; researchers have relied upon responses from a single spouse; financial management has been defined on only one or a limited number of dimensions; and variations found among responding families have been left unexplained or related to only one or two demographic variables. These studies can be classified into three

*Dennis L. Rosen is Assistant Professor of Marketing and Donald H. Granbois is Professor of Marketing, Graduate School of Business, Indiana University, Bloomington, IN 47405 . The authors are grateful to Franklin Acito for his many helpful suggestions and assistance in data analysis, and to Ralph Day, Richard Olshavsky, and anonymous reviewers for their comments on the manuscript. categories: money management, savings and investment, and sex-role attitudes.

\section{Money Management}

Reviewing the few existing studies on money management, Ferber (1973) concluded that the most common arrangement is for wives to handle money and bills. Ferber and Lee (1974) reported data identifying the "family financial officer" (FFO) in a panel restricted to newlywed couples who answered only three financial-task questions. Readministration to the couples 12 months later revealed a marked tendency away from joint performance of these tasks to performance by the wife alone. Differences in education or wife's employment status had no influence on which spouse was the FFO.

In a more recent small study (100 young couples with a firstborn child under five months old), joint responsibility was the predominant pattern reported for questions about "who makes" and "who implements" a series of money management tasks (Lovingood and Firebaugh 1978). In a study of 40 dual-career families with one or more children at home, both husbands and wives reported joint involvement in savings and investment decisions for about half the couples studied (Niffenegger, Taylor, and Taylor 1980). A larger panel study by Schaninger, Buss, and Grover (1982) analyzed husbands' and wives' response to a series of questions asking "who handles/decides" for a number of expenditures and financial management categories. Sex-role norm responses were found to be related to role structure, but the homogeneity of the panel precluded any analysis of demographic determinants of role structure.

Thus, previous research yields no precise generalizations about family role structure in money-management tasks. Only very general measures of these tasks have been used, and perhaps because of the special populations studied, only a very tentative explanation has been offered for differences in role structures among families. 


\section{Savings and Investment}

Ferber's review of studies on family saving and investment behavior concluded that the research was useful in explaining the "end product" of family decision making on saving, but revealed nothing about "how these decisions were made in the first place or the roles of the different members in defining these objectives" (1973, p. 51). Ferber did report a finding (Wolgast 1958) based on a single question about "seeing that money gets saved," which showed that nearly half the reporting families decided jointly. In contrast, Ferber and Nicosia's newlywed panel reported joint savings decisions in 80 percent of the cases (Ferber 1973, p. 52).

\section{Sex-Role Attitudes in Financial Management}

Sex-role attitude measures were included in four studies of family role structure in which at least one question on financial management was included. Although no clear pattern emerges, results encourage further investigation of sexrole attitudes. Green and Cunningham (1975) identified liberal and conservative attitudes with respect to women's roles in society among 257 Houston women. No significant difference was found on aspects of saving, but the liberals reported less joint handling of money and bills than did moderates and conservatives.

In a replication of the role structure study by Davis and Rigaux (1974), Bonfield (1978) found only a modest difference between responses by "traditional", (husband-masculine, wife-feminine) and all families, when individual husbands and wives were classified as masculine, feminine, or androgynous based upon response to the Bem Sex Role Inventory. Qualls (1982) used the Sex Role Attitude scale developed by Osmond and Martin (1975) to classify both husbands and wives as either modern or traditional. Traditional husbands rated the decision of how much to save each period as strongly husband dominant, and modern husbands felt the pattern should be, slightly husband dominant, yet both traditional and modern wives felt that the pattern should be one of joint influence. Schaninger et al. (1982) performed a factor analysis on sexrole responses to a scale based on that of Scanzoni (1975). Three of the four retained factors were found to be related to family financial management. Sex-role "moderns" demonstrated less husband influence and more joint influence than did more traditional couples.

\section{THEORETICAL DEVELOPMENT}

Hempel and Tucker (1980) used contingency theory, social conflict, and family decision theory literature as the basis for several propositions about family roles in financial decisions. The three major variables emerging from their theoretical discussion-wife's working status and motivation for work, life-cycle stage, and husbands' and wives' sex-role attitudes-paralleled those determinants of change identified by Roberts (1981) and were incorporated in the design of our study.

\section{Sex-Role Attitudes}

Sociologists have discussed men's and women's normative sex-role attitudes, and scales to measure these attitudes have been developed and administered in various settings (Tomeh 1978). Unlike earlier conceptions of masculinity-femininity, which tended to confuse sex-role preference, sex-role adoption, and sex-role identity (Brogan and Kutner 1976), these normative attitudes refer to what people consider appropriate male and female behaviors. Early developers of normative scales emphasized a type of equality-inequality continuum, but such scales now tend to emphasize roles of both sexes in terms of a "traditional" (sharply dichotomous roles for males and females) versus a "modern" (role sharing between the sexes) continuum.

Research on the incidence of traditional and modern sexrole attitudes suggests that modern attitudes are more likely to be found among respondents who are younger, more highly educated, and higher in social status (Filiatrault and Ritchie 1980). There is considerable support for the conclusion that, although both men's and women's attitudes toward the appropriate roles for both men and women have undergone change, "traditional" as well as "modern" groups still exist among both sexes.

The Osmond-Martin Sex-Role Attitude scale (Osmond and Martin 1975) provided the sex-role attitude measures used in the present study. The scale distinguishes traditional (sex differentiated) and modern (undifferentiated) attitudes toward roles for both males and females in four spheres: familial roles, extrafamilial roles, stereotypes of male/female nature and behavior, and social change as related to sex roles.

\section{Locus of Control}

Another element in the conceptualization of the present study, locus of control, introduces a personality variable suggested by several earlier consumer studies. Locus of control, which classifies individuals in the extreme as "internals" (perceiving events in their lives as resulting from their own action) and "externals" (perceiving their lives as affected by uncontrollable forces), was found to be related to such variables as behavior intention toward new products and use of varying types of information in decision making (Mazis and Sweeney 1973; Nielsen and Stanton 1973).

Research in psychology provides evidence that locus of control may be broadly related to decision making, although its relationship to family role structure apparently has not been studied (see Lefcourt 1972 for a review). There seems to be intuitive support for the notion that internals and externals may also differ in their roles concerning family financial decisions and tasks.

\section{Hypothesized Relationships}

We hypothesized that family financial role structure would be some function of husband/wife sex-role attitude, locus of control, wife's working status/motivation, and de- 
mographic variables. It was further expected that the relative importance of the variables influencing role structure would differ for those tasks involving implementation versus those involving decision making. It was not possible, however, to state the direction of these hypothesized relationships, since their nature or direction was not suggested by previous research or theory.

\section{PROCEDURE}

In-home interviews were required because of the sensitive nature of the questions involved. Respondents were 82 couples drawn from the city directory of Bloomington, Indiana. We employed a stratified random sampling procedure to offset the limitations of the small, geographically specific sample. Starting with randomly selected listings, families were selected to balance income level (upper/ lower) and wife's employment status.

The highly structured interview covered two broad areas of financial management activities. One area, bookkeeping and other paper-handling activities that implement decisions, included questions on who balanced checkbooks, reconciled checkbooks, corrected checkbook errors, reconciled savings statements, and paid bills. Questions on actual decision-making activities included who decided the method of saving, amounts to be contributed to savings, number and ownership of checking accounts, items and amounts for the monthly budget, what to do with leftover money at the end of the month, the system of budgeting and/or spending from income, the methods of financing purchases, the priority for paying bills in general, and the amounts to pay on three different kinds of credit card bills. Questions on investment decisions were not included, partly to keep the interview at a reasonable length (under 90 minutes) and partly because we expected that many families would not have investment activities to report. The interview was administered when both the husband and wife could be present.

Respondents were asked to indicate whether each operation was handled by the wife mostly, husband mostly, wife alone and husband alone with equal frequency, or both jointly. A single response from a couple was required in each case, following a discussion between husband and wife, if necessary. Couples then individually completed Osmond and Martin's (1975) Sex-Role Attitude (SRA) Scale and Rotter's (1966) Locus of Control Scale. Finally, standard demographic questions were asked.

The decision to interview both husband and wife jointly was based on findings of past research indicating that role behaviors cannot be adequately reported by either husband or wife alone. Davis (1970) compared independent responses on auto and furniture decision role structure questions from husbands and wives in 100 Chicago families. Agreement was found for only about 60 percent of the couples. His findings were similar to those of earlier studies (Ferber 1955; Granbois and Willett 1970; Scanzoni 1965), leading him to conclude that "When assessing influence is a prelude to further research, then questioning
TABLE 1

COMPONENT LOADINGS FOR DECISION CROSS-PRODUCT MATRIX FOLLOWING VARIMAX ROTATION ${ }^{\mathrm{a}}$

\begin{tabular}{lcc}
\hline \multicolumn{1}{c}{ Decisions } & $\begin{array}{c}\text { Component 1 } \\
\text { (Group 1) }\end{array}$ & $\begin{array}{c}\text { Component 2 } \\
\text { (Group 2) }\end{array}$ \\
\hline Number/ownership-Checking & .79 & \\
$\quad$ accounts & .74 & \\
Method of financing & .71 & \\
Method of saving & .66 & \\
Handling of leftover money & .66 & \\
System of handling spending & .45 & .95 \\
Amount/item in budget & & .86 \\
Amount to pay-Bank cards & & .71 \\
Amount to pay-Department store & & \\
cards & & \\
Priority order for bill payment & & \\
\hline
\end{tabular}

${ }^{\text {a }}$ To facilitate interpretation, only loadings greater than 0.35 are shown.

${ }^{\mathrm{b}}$ The decision concerning the amount to pay on oil company credit cards was excluded from the analysis because of its high correlation with that for bank credit cards.

one spouse is not sufficient since discrepancies within the family become important'” (Davis 1971, p. 306).

Nevertheless, joint interviewing may introduce biases, since it is possible for one spouse to dominate and force a view on the other. We felt this disadvantage was balanced by the advantage of providing couples with the opportunity to discuss their responses, which was particularly important because the questions involved role structure topics that many had not previously considered. Interviewers reported that the couples were able to agree on the role structure questions with little difficulty. In addition, the presence of both husband and wife facilitated the acquisition of independent responses from both spouses on the personality and attitude measures - a desirable aspect not often found in family role structure research.

\section{ANALYSIS}

The analysis was intended to identify variables that are important in determining family financial role structure for both implementation and decision-making tasks. A method was employed to determine whether further subgroupings of tasks existed within this two-fold breakdown. A coding system designated each household-according to a frequently observed breakdown in the sample-as predominantly husband or wife dominant for implementation tasks (coded 1 and -1 , respectively) and as separate or joint for decision-making tasks (coded 1 and -1 , respectively). Six households were eliminated from the analysis of implementation tasks because they could not be classified in this manner (e.g., equal split between husband and wife, or tasks performed jointly rather than separately). For similar reasons, 14 households were eliminated from the analysis of decision tasks. In both cases, the households represented too small a group for separate consideration. The average of the cross-products for each pair of implementation tasks 
TABLE 2

COMPONENT LOADINGS FOR RESPONDENT CHARACTERISTICS

\begin{tabular}{|c|c|c|c|c|c|}
\hline \multirow[b]{2}{*}{$\begin{array}{l}\text { Respondent } \\
\text { characteristics }\end{array}$} & \multicolumn{5}{|c|}{ Components } \\
\hline & $\begin{array}{c}\text { Wife's } \\
\text { sex-role attitude } \\
\text { and education }\end{array}$ & $\begin{array}{l}\text { Husband's } \\
\text { sex-role attitude } \\
\text { and education }\end{array}$ & $\begin{array}{l}\text { Husband/wife social } \\
\text { change as related } \\
\text { to sex-role } \\
\text { attitude }\end{array}$ & $\begin{array}{l}\text { Husband/wife } \\
\text { locus of } \\
\text { control }\end{array}$ & $\begin{array}{l}\text { Family } \\
\text { life } \\
\text { cycle }\end{array}$ \\
\hline Sex-role stereotype-Wife & .88 & & & & \\
\hline Extrafamilial roles-Wife & .76 & & & & \\
\hline Education-Wife & .71 & & & & \\
\hline Familial roles-Wife & .68 & & & & \\
\hline Education-Husband & -.57 & -.60 & & & \\
\hline Sex-role stereotype-Husband & & .87 & & & \\
\hline Familial roles-Husband & & .78 & & & \\
\hline Extrafamilial roles-Husband & & .74 & & & \\
\hline Social change-Wife & & .48 & .56 & & \\
\hline Social change-Husband & & & .84 & & \\
\hline Locus of control-Husband & & & & .81 & \\
\hline Locus of control-Wife & & & & .76 & \\
\hline Family income & & & & & .80 \\
\hline Years married & & & & & .75 \\
\hline
\end{tabular}

Note: To facilitate interpretation, only loadings greater than .35 are shown.

and decision tasks indicated sex-role similarity across remaining households for that task pair.

The similarity measures for implementation and decision tasks were submitted separately to a principal components analysis using varimax rotation, with resultant loadings indicating any subgroupings of kinds of tasks based on similarity. A single component accounted for 88.5 percent of the variance in implementation tasks, indicating that no further subdivision of these tasks was necessary. However, analysis of decision tasks indicated that decisions on the priority for paying bills and amounts to pay for three different kinds of credit cards grouped separately from all other decision tasks. Thus we labeled the two decision components Group 1 and Group 2 (see Table 1).

Next, the independent variables (four SRA subscales, locus of control scores, education of husband and wife, years married, and household income) were submitted to a principal components analysis with varimax rotation to produce a set of uncorrelated variates. Five components were found as shown in Table 2. Two dummy variables reflecting wife's working status and reason for workingfinancial versus self-fulfillment-were added to form the final set of independent measures. A step-wise discriminant function analysis was then performed separately on the data for the implementation tasks and each of the two decision task groups (from Table 1) to determine which of the independent variables were significant in determining sex-role attitude (husband versus wife for implementation; joint versus separate for decision making).

\section{RESULTS AND DISCUSSION}

Results of the discriminant function analysis were interpreted using standard methods (Klecka 1980) to find those variables that were most important in determining family financial role structure for each of the decision task groupings. Table 3 shows results for these variables, including the contribution of each to the discriminant function (standardized coefficient), its correlation with the discriminant function (structure coefficient), and the statistical significance of the discriminant function with the listed variables entered (Wilks lambda).

A clear distinction was indicated in role performance between implementation and decision-making financial activities. Wife's sex-role attitude and education, husband's sex-role attitude and education, and husband/wife social change as related to sex-role view were clearly significant for implementation tasks across all indicators. Here the wife tends to be in charge when husband's and wife's sex-role attitudes and social change views are more traditional and when educational level is low.

An analysis of the Group 1 decision tasks found only the locus of control component to be significant. The results indicate that separate decision making is more likely to occur for these tasks when the couple has an external locus of control. Possibly “externals," feeling a lack of control, do not perceive a need to invest time in the discussion of these activities. One spouse may simply perform them in a perfunctory manner. Couples with a more internal locus of control may attribute more importance to the decision and hence employ joint decision making.

For Group 2 decision tasks (payment amounts on credit card accounts and priority for bill payment), one dummy variable reflecting wife's working status and motivation (Working wife 1) made the greatest contribution to the discriminant function. This indicates that these financial decisions are more likely to be made by the wife and husband separately when the wife is working for financial reasons. 
TABLE 3

STEP-WISE DISCRIMINANT ANALYSIS FOR FINANCIAL TASKS

\begin{tabular}{clccc}
\hline \hline \multirow{2}{*}{ Task type } & \multicolumn{1}{c}{$\begin{array}{c}\text { Discriminating } \\
\text { variables }\end{array}$} & $\begin{array}{c}\text { Stand- } \\
\text { ardized } \\
\text { coeffi- } \\
\text { cients }\end{array}$ & $\begin{array}{c}\text { Struc- } \\
\text { ture } \\
\text { coeffi- } \\
\text { cients }\end{array}$ & $\begin{array}{c}\text { Wilks } \\
\text { lambda }\end{array}$ \\
\hline Implementation & Wife Sex-role/Ed. & .57 & .54 & \\
& Hus. Sex-role/Ed. & .60 & .53 & \\
& Social Change & .56 & .47 & $.78^{\text {d }}$ \\
Group 1 decision & Locus of control & .83 & .78 & $.85^{\text {d }}$ \\
Group 2 decision & Working wife 1 & .74 & .71 & \\
& Family life cycle & .64 & .59 & $.84^{c}$ \\
\hline
\end{tabular}

${ }^{\mathrm{a}} \mathrm{N}$ for Implementation = 58; Group 1 decision $=63 ;$ Group 2 decision $=51 ;$ Households with missing data on one or more discriminant variables were eliminated from the analysis. Degrees of freedom omitted to conserve space.

'Part of dummy variable coding for working status and motivation:

Working wife 1-financial (1); fulfillment $(0)$; not working $(0)$.

Working wife 2-financial (0); fulfillment (1); not working (0).

${ }^{c} p<0.05$

${ }_{p}<0.01$.

Whether or not the wife is working when self-fulfillment is the motivation for work (Working wife 2) offered no significant discrimination between groups. Also significant was the "family life cycle" component, indicating that separate decision making increases with years married and family income level.

Thus it would appear that role structure is more complex than previously thought. We found a difference in variables associated with role structure for implementation as opposed to decision task variables. This is important for managerial reasons (e.g., targeting by financial institutions of family decision maker for services offered) as well as for theoretical reasons. Yet the distinction has not been clearly made in past research. For example, one could argue that the "decision" measures of "bill paying" and "keeping track of expenditures in relation to budgets" used by Ferber and Lee (1974) to define the family financial officer are actually measures of implementation.

Our research found that those decision tasks concerning the method of savings, the amount to be saved, the number and ownership of checking accounts, and the system of budgeting and handling leftover funds show a similar role structure. All represent basic policy issues of the sort that, once established, tend to control financial behavior over long periods of time and that require only occasional adjustments. On the contrary, establishing the priority for bill payment and deciding amounts to be paid on credit card accounts represent a separate decision task group, since these tasks represent short-run adjustments between resources acquired and obligations made each pay period. Role structure and the variables determining role structure also differ for these two groups of decision tasks.

Two of our findings have particular importance given current social trends. First, in contrast to earlier research, this study found that husbands tended to handle implemen- tation tasks in a substantial proportion of households. If one assumes that our society is showing a trend toward more people going to college and more egalitarian sex-role views, this finding would suggest that the husband's importance in this task area will increase. Second, it is interesting that wife's working status/motivation is significant as a role structure determinant for the Group 1 decision tasks. The trend toward married women working is clear, and recent economic conditions may have led more of these women to perceive their reason for working as financial rather than as self-fulfillment. According to our findings, the result should be a greater tendency toward separate decision making in this area.

Note that the small size and geographic specificity of our sample restricts generalization and requires further research to clarify our findings. Nevertheless, it would appear from the overall results that socioeconomic and demographic variables (except for education) are less predictive of which partner handles financial matters than is sex-role attitude and education. Thus, given the likelihood of changes in educational level and sex-role attitudes, findings from earlier studies may no longer be valid.

[Received August 1982. Revised June 1983.]

\section{REFERENCES}

Bonfield, Edward H. (1978), "Perception of Marital Roles in Decision Process: Replication and Extension," in Advances in Consumer Research, Vol. 5, ed. H. Keith Hunt, Ann Arbor, MI: Association for Consumer Research, 300-307.

Brogan, Donna and Nancy G. Kutner (1976), "Measuring SexRole Orientation: A Normative Approach," Journal of Marriage and the Family, 38 (February), 31-40.

Davis, Harry L. (1970), "Dimensions of Marital Roles in Consumer Decision Making," Journal of Marketing Research, 7 (May), 168-177.

- (1971), "Measurement of Husband-Wife Influence in Consumer Purchase Decisions," Journal of Marketing Research, 8 (August), 305-312.

and Benny P. Rigaux (1974), "Perception of Marital Roles in Decision Processes," Journal of Consumer Research, 1 (June), 56-61.

Ferber, Robert (1955), "On the Reliability of Purchase Influence Studies," Journal of Marketing, 19 (January), 225-232.

(1973), "Family Decision Making and Economic Behavior: A Review," in Family Economic Behavior: Problems and Prospects, ed. Eleanor B. Sheldon, Philadelphia, PA: J. B. Lippincott, 29-61.

and Lucy Chao Lee (1974), "Husband-Wife Influence in Family Purchasing Behavior," Journal of Consumer Research, 1 (June), 43-51.

Filiatrault, Pierre and J. R. Brent Ritchie (1980), "Joint Purchasing Decisions: A Comparison of Influence Structure in Family and Couple Decision-Making Units," Journal of Consumer Research, 7 (September), 131-140.

Granbois, Donald H. and Ronald P. Willett (1970), "Equivalence of Family Role Measures Based on Husband and Wife Data," Journal of Marriage and the Family, 32 (February), 68-72.

Green, Robert T. and Isabella C. M. Cunningham (1975), "Fem- 
inine Role Perception and Family Purchasing Decisions,', Journal of Marketing Research, 12 (August) 325-332.

Hempel, Donald J. and Lewis R. Tucker (1980), "Issues Concerning Family Decision Making and Financial Services,' in Advances in Consumer Research, Vol. 7, ed. Jerry C. Olson, Ann Arbor, MI: Association for Consumer Research, 216-220.

Klecka, William R. (1980), Discriminant Analysis, Beverly Hills, CA: Sage.

Lefcourt, Herbert M. (1972), "Recent Developments in the Study of Locus of Control," in Progress in Experimental Personality Research, Vol. 6, ed. Brendan A. Maher, New York: Academic Press, 1-39.

Lovingood, Rebecca P. and Francille M. Firebaugh (1978), "Household Task Performance Roles of Husbands and Wives," Home Economics Research Journal, 7 (September), 20-33.

Mazis, Michael B. and Timothy W. Sweeney (1973), "Novelty and Personality with Risk as a Moderating Variable,"' in Combined Proceedings: Marketing Education and the Real World and Dynamic Marketing in a Changing World, eds. Boris W. Becker and Helmut Becker, Chicago: American Marketing Association, 406-411.

Nielsen, Richard P. and John Stanton (1973), "Type of Information Sensitivity, Fatalism, and Spending Behavior," in Combined Proceedings: Marketing Education and the Real World and Dynamic Marketing in a Changing World, eds Boris W. Becker and Helmut Becker, Chicago: American Marketing Association, 400-405.

Niffenegger, Phillip B., Jan Cooper Taylor, and Ronald D. Taylor (1980), "Consumer Decision Allocation of Spouses in Dual Career Families: A Descriptive Study,' unpublished working paper, Department of Marketing, Murray State University, Murray, KY 42071.

Osmond, Marie W. and Patricia Y. Martin (1975), "Sex and Sexism: A Comparison of Male and Female Sex-Role Attitudes," Journal of Marriage and the Family, 37 (November), 744-758.

Qualls, William (1982), "Changing Sex Roles: Its Impact Upon Family Decision Making," in Advances in Consumer Research, Vol. 9, ed. Andrew Mitchell, Ann Arbor, MI: Association for Consumer Research, 267-270.

Roberts, Mary Lou (1981), “Women's Changing Roles-A Consumer Behavior Perspective," in Advances in Consumer Research, Vol. 8, ed. Kent Monroe, Ann Arbor, MI: Association for Consumer Research, 590-595.

Rotter, Julian B. (1966), "Generalized Expectancies for Internal Versus External Control of Reinforcement," Psychological Monographs, 80(1), Whole No. 609.

Scanzoni, John (1965), "A Note on the Sufficiency of Wife Responses in Family Research," Pacific Sociological Review, $8,109-115$

(1975), "Sex Roles, Economic Factors, and Marital Solidarity in Black and White Marriages," Journal of Marriage and the Family, 37, 130-144.

Schaninger, Charles M., W. Christian Buss, and Rajiv Grover (1982), "The Effect of Sex Roles on Family Finance Handling and Decision Influence," 1982 Educators Conference Proceedings, Chicago: American Marketing Association.

Tomeh, Aida K. (1978), "Sex-Role Orientation: An Analysis of Structural and Attitudinal Predictors," Journal of Marriage and the Family, 40, 341-354.

Wolgast, Elizabeth (1958), "Do Husbands or Wives Make the Purchasing Decisions?" Journal of Marketing, 23, 151-158. 